УДК 546.14:581.45:582.681.82:550.42

\title{
БРОМ В ЛИСТЬЯХ ТОПОЛЯ УРБАНИЗИРОВАННЫХ ТЕРРИТОРИЙ: ПРИРОДНЫЕ И АНТРОПОГЕННЫЕ ИСТОЧНИКИ ПОСТУПЛЕНИЯ
}

\author{
Юсупов Дмитрий Валерьевич1,2, \\ yusupovd@mail.ru
}

\section{Рихванов Леонид Петрович2}

Барановская Наталья Владимировна², natalya.baranovs@mail.ru

Робертус Юрий Владимирович ${ }^{3}$, ariecol@mail.gorny.ru

\author{
Радомская Валентина Ивановна 4 , \\ radomskaya@ascnet.ru
}
Павлова Людмила Михайловна 4 , pav@ascnet.ru

\author{
Дорохова Любовь Александровна2,4, \\ liubov.ad@yandex.ru
}

\section{Судыко Александр Федорович2, sudykoaf@yandex.ru}

\footnotetext{
1 Амурский государственный университет, Россия, 675027, г. Благовещенск, Игнатьевское шоссе, 21.

2 Национальный исследовательский Томский политехнический университет, Россия, 634050, г. Томск, пр. Ленина, 30.

3 Институт водных и экологических проблем СО РАН, Россия, 656038, г. Барнаул, ул. Молодежная, 1.

4 Институт геологии и природопользования ДВО РАН, Россия, 675000, г. Благовещенск, пер. Рёлочный, 1.
}

\begin{abstract}
Актуальность исследования. Бром является толассофильным, органофильным и эссенциальным элементом. Сочетание природно-антропогенных источников рассеяния этого элемента обуславливает комплексность и многофакторность его поступления в окружающую среду, оказывает влияние на особенности накопления и распределения галогена в природных средах. Основное внимание в работе сосредоточено на урбанизированных территориях локального и регионального уровней исследования с источниками эмиссии Br. Пути миграции и биогеохимической аккумуляции брома остаются слабо изученными вопросами.

Цель: определить количественные содержания $\mathrm{Br}$ в листьях древесных растений рода тополь (Populus L.), nроизрастающих на урбанизированных территориях юго-востока Евразии, и на основе принципов биогеохимического районирования выявить ореолы Вr нагрузки, определить главные факторы их формирования.

Объект и методы. Объектом исследования являлись листья тополя (Populus L.). Отбор проб проведен в августе 2015-2018 г2. на территории 50 городов по равномерной сети с шагом 1×1 и 2×2 км. Средний объем выборок в городах составил 30 проб. Всего отобрано 1686 проб листьев тополя. Озоление листьев проводилось методом сухой минерализации в мусрельной печи при температуре $450^{\circ} \mathrm{C}$ в течение 5 час. Принимались во внимание литературные данные о том, что потери $\mathrm{Br}$ в золе, полученной при $400{ }^{\circ} \mathrm{C}$, составляют не более $20 \%$ от расчетной величины. Определение содержания $\mathrm{Br}$ и других химических элементов в золе листьев тополя проводилось методом инструментального нейтронно-активационного анализа в ядерно-геохимической лаборатории на исследовательском учебном ядерном реакторе (ИРТ-Т) в Томском политехническом университете. Результать анализов обработаны методами описательной статистики, кластерного и дискриминантного анализов.

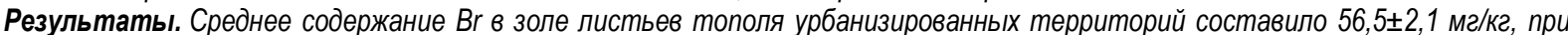
разбросе от 0,3 до 1730,1 мг/ке. Медиана - 30,6 мг/ке. Нижнее аномальное содержание Br составило 103,4 мг/к2. Выявлены две сопряженные аномальные бромные биогеохимические области: Кулундинская - природного генезиса, и СевероКазахстанская - природно-техногенного генезиса. Области объединены в бромную биогеохимическую субпровинцию, впервые описываемую в данной работе.
\end{abstract}

\section{Ключевые слова:}

Биогеохимическая индикация, листья тополя, бром, инструментальный нейтронно-активационный анализ, урбанизированная территория.

\section{Введение}

$\mathrm{Br}$ - редкий, летучий, токсичный неметалл; относится к группе редких и рудных р-элементов, общей особенностью которых является низкая распространенность в земной коре. Кларки $\mathrm{Br}$ составляют для литосферы - 2,4 г/т, для биосферы - 26 г/т, для гидросферы - 67 г/т. По геохимическим свойствам $\mathrm{Br}$ относят к био-, атмо- и гидрофильным элементам, а по минералого-геохимическому поведению в земной ко- ре - к литофильным и галогенофильным [1]. Основными накопителями $\mathrm{Br}$ являются осадочные породы, особенно илы соляных озер. В рассолах артезианских бассейнов содержание $\mathrm{Br}$ достигает 0,4 \%. Области накопления $\mathrm{Br}$ находятся в аридных и семиаридных климатических зонах и связаны с эвапоритами. Собственные минералы - бромиды - $\mathrm{Br}$ образует редко [2], в основном встречается в виде изоморфной примеси в минералах-галоидах: галите, сильвините, кар- 
наллите, бишофите, присутствует в арагоните, сорбируется $\mathrm{Ca}_{\text {орг }}$. В морской воде содержание $\mathrm{Br}$ на 2-3 порядка выше, чем в пресных водах; повышенное его содержание наблюдается и в атмосферных осадках прибрежных морских территорий $[3,4]$. Для углей $\mathrm{Br}$ является органофильным и типоморфным элементом за счет обогащения из формирующей их растительности - кларк $\mathrm{Br}$ в бурых углях - 4,4 $\pm 0,8$ г/т, в золе $-32,0 \pm 5$ г/т; в каменных углях $-6,0 \pm 0,8$ г/т, в 30ле - 32,9 г/т [5]. В растениях средние содержания $\mathrm{Br}$ одни из самых высоких и могут достигать, например, для морских растений 740 мг/кг, наземных - 15 мг/кг. Даже в культурных наземных растениях природное содержание $\mathrm{Br}$ варьирует от 0,002 до 120 мг/кг [1].

Технофильность Вr высокая - 1,5*109 [1], при этом с экогеохимических позиций и по биозначению $\mathrm{Br}$ характеризуется слабой изученностью. Содержание $\mathrm{Br}$ в окружающей среде увеличивается за счет промышленных выбросов, работы автотранспорта, сжигания органического топлива [6-9]. Аэротехногенная эмиссия Вr наблюдается при различных технологиях сжигания углей [5]. На тепловых электростанциях при пылеугольном сжигании $\mathrm{Br}$ концентрируется в тонкой фракции золы уноса, минуя электрофильтры, что свидетельствует о его переходе в газовую фазу. При низких температурах озоления $\left(120^{\circ} \mathrm{C}\right)$ от исходного содержания $\mathrm{Br}$ теряется 47-85\%, тогда как в золе, полученной при $400{ }^{\circ} \mathrm{C}$, остаточное количество $\mathrm{Br}$ составляет порядка $80 \%$ от расчетной величины. При $800{ }^{\circ} \mathrm{C} \mathrm{Br}$ уходит из золы практически полностью - на 98-100 \% [10]. Около 80 \% промышленного производства брома приходится на его органические соединения [11], которые, попадая в окружающую среду даже в малых концентрациях, обладают общетоксическим, эмбриотропным, гонадотропным, мутагенным действием [12-16].

Таким образом, на локальных территориях может наблюдаться загрязнение окружающей среды бромсодержащими соединениями [17]. При этом многие аспекты формирования атмогеохимических бромных аномалий до сих пор остаются недостаточно изученными.

При мониторинге состояния окружающей среды урбанизированных территорий хорошим биогеохимическим индикатором могут служить листья тополя [18-22]. Сорта, гибриды, клоны тополя бальзамического широко используются для защитных и озеленительных насаждений в промышленных, селитебных и рекреационных зонах городов из-за его устойчивости к задымлению, высокой способности к газообмену и пылеподавлению. Известно, что листья тополей, произрастающих на урбанизированных территориях, содержат в 26-60 раз больше $\mathrm{Br}$ по сравнению с таковыми из пригородов [23]. На преимущественно воздушный путь миграции и биоаккумуляции $\mathrm{Br}$ косвенно указывает тот факт, что в листьях растений $\mathrm{Br}$ coдержится больше, чем в других органах, и концентрация элемента при этом не зависит от типа почв, его содержания в почвах, величины $\mathrm{pH}$ [24].

Цель работы - определить количественные содержания $\mathrm{Br}$ в листьях древесных растений рода тополь
(Populus L.), произрастающих на урбанизированных территориях юго-востока Евразии, и на основе принципов биогеохимического районирования выявить ореолы $\mathrm{Br}$ нагрузки, определить главные факторы их формирования.

\section{Материалы и методы исследования}

Полевые исследования проводили на территории 50 городов юга Азиатской части России и северовостока Казахстана в период с 2013 по 2018 гг. по единой стандартной методике [25]. Объектом исследования служили листовые пластинки тополя трех видов: черного (Populus nigra L.), душистого (Populus suaveolens Fisch.) и бальзамического (Populus balsamifera L.).

Отбор проб листьев проводили с августа по сентябрь: в крупных городах и городах-миллионниках по площадной сети $2 \times 2$ км; в малых и средних городах $-1 \times 1$ км. Отбор проб в каждом городе производился в течение одного дня. Листья отбирали по окружности кроны на высоте 2-2,5 м с одновозрастных деревьев одного вида в ясную погоду, паковали в пакеты из влагопрочной бумаги. Всего было отобрано 1686 проб, из которых 90 \% представлены листьями тополя бальзамического (Populus balsamifera L.).

Подготовка проб к анализу заключалась в двухэтапной сухой минерализации (озолении) листьев: высушенную биомассу первоначально обугливали в фарфоровых чашках на электроплитке до прекращения выделения дыма; полученную золу переносили в тигли и затем прокаливали в электропечи - 2 часа при постепенном повышении температуры от 250 до $450{ }^{\circ} \mathrm{C}\left(50{ }^{\circ} \mathrm{C}\right.$ через 30 минут) и 3 часа при постоянной температуре $450{ }^{\circ} \mathrm{C}$ [26]. В результате получали золу белого или светло-серого оттенка, которую после остывания дополнительно растирали в агатовой ступке.

Для определения содержания $\mathrm{Br}$ и других элементов в золе листьев тополя использовали метод инструментального нейтронно-активационного анализа (ИНАА) на тепловых нейтронах [27]. Методика ИНАА заключается в облучении исследуемых проб потоком тепловых нейтронов в реакторе и последующем измерении наведенной активности на гаммаспектрометре с полупроводниковыми детекторами. Метод является неразрушающим, не требующим химической подготовки пробы, обладает высокой чувствительностью и точностью в диапазоне содержаний от $\mathrm{n}^{1} \%$ до $\mathrm{n} \cdot 10^{-8} \%$. Помехи от матричных или других элементов могут быть исключены или нивелированы варьированием продолжительности облучения и охлаждения.

ИНАА проводили в аккредитованной ядерногеохимической лаборатории (аттестат аккредитации № RA.RU.21АБ27) на исследовательском ядерном реакторе ИРТ-Т в Национальном исследовательском Томском политехническом университете по аттестованным методикам (НСАМ ВИМС № 410-ЯФ). В капсюли из алюминиевой фольги марки А-995 помещали навески золы (по 100土1 мг) исследуемых образцов и золу листьев березы ЛБ-1 в качестве эталона 
(8923-2007); заполненные капсюли переносили в контейнер для облучения. Продолжительность облучения проб в канале реактора составляла 20 часов с плотностью потока тепловых нейтронов порядка $1 \cdot 10^{13}$ нейтрон $/ \mathrm{cm}^{2} \cdot \mathrm{c}$. Аттестованное значение концен-

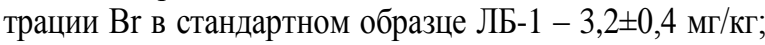
погрешность определения содержания элементов не более $30 \%$.

Результаты ИНАА обрабатывали методами описательной статистики, корреляционного, кластерного и дискриминантного анализов.

\section{Результаты и их обсуждение}

Среднее содержание $\mathrm{Br}$ в золе листьев тополя во всей выборке (1686 проб) составило 56,5 $\pm 2,1$ мг/кг (медиана - 30,6 мг/кг) при разбросе значений от 0,3 до 1730,1 мг/кг. Медианное значение принято за средний региональный уровень содержания Br. Установлен ло- гарифмически нормальный закон распределения содержания $\mathrm{Br}$ в выборке. Проверку соответствия распределения $\mathrm{Br}$ гипотезе логнормального закона производили по показателям асимметричности и эксцесса. За нижнее аномальное значение принято произведение среднего геометрического и стандартного множителя [28]. Нижнее аномальное содержание $\mathrm{Br}$ составило 103,4 мг/кг. Принята следующая градация показателей содержаний $\mathrm{Br}$ : менее 30 мг/кг - ниже регионального уровня; 30-99 мг/кг - средний и выше регионального уровня, но ниже аномального содержания; 100-200 мг/кг - аномальный уровень; более 200 мг/кг максимальный аномальный уровень содержаний.

Уровни накопления $\mathrm{Br}$ в золе листьев тополя на исследованных урбанизированных территориях северо-востока Казахстана и азиатской части России показаны на рис. 1.

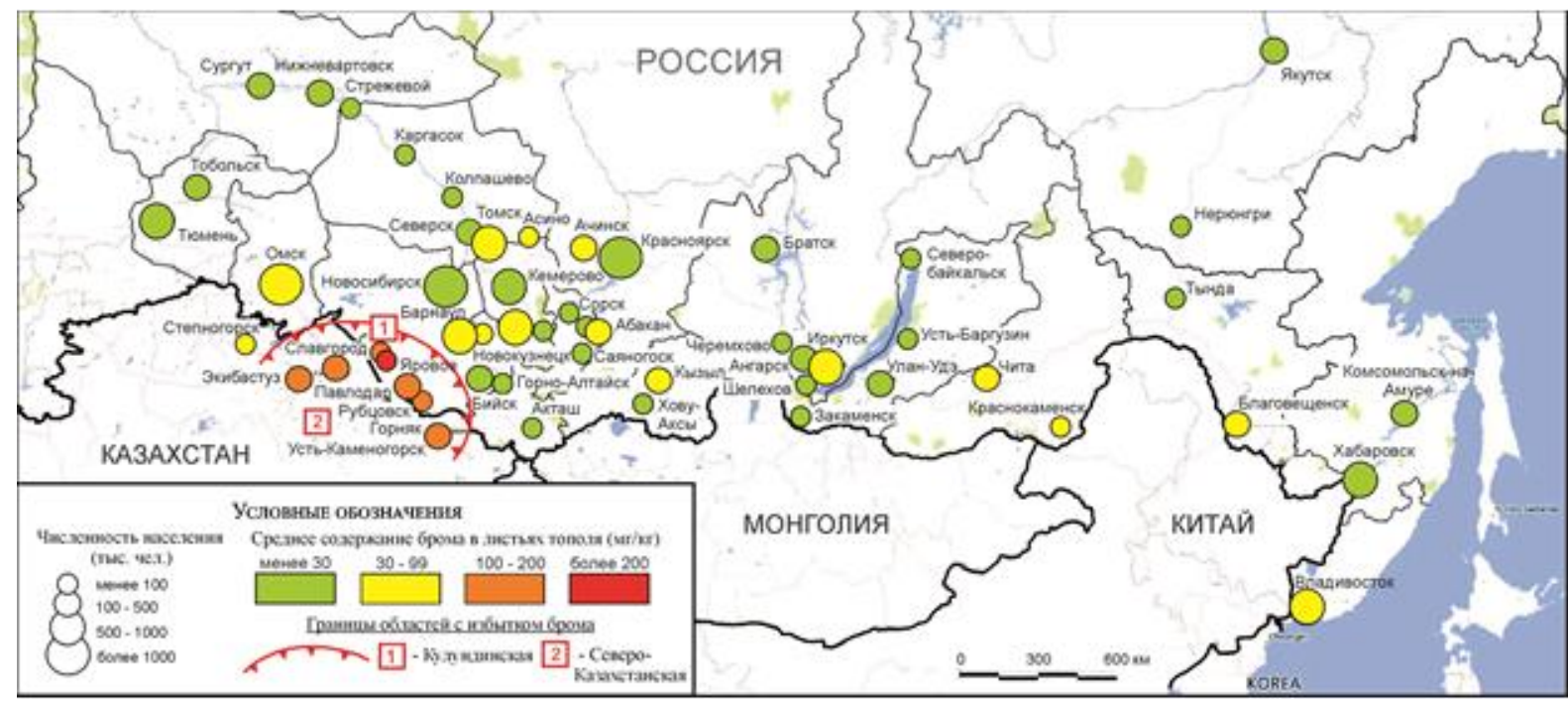

Pис. 1. Территория исследования. Распределение содержания брома в листьях тополя на урбанизированных территориях северо-восточного Казахстана, юга Сибири и Дальнего Востока

Fig. 1. Study area. Distribution of bromine content in poplar leaves in the urbanized territories of north-eastern Kazakhstan, Siberia and the Far East

На региональном уровне четкой зависимости (геохимической зональности) в распределении диапазона средних содержаний $\mathrm{Br}$ в золе листьев тополя, произрастающих на исследованных урбанизированных территориях, не выявлено. На этих территориях, находящихся в диапазоне среднего уровня содержаний $\mathrm{Br}$, закартированы локальные биогеохимические аномалии (указаны максимальные содержания в выборке в мг/кг): Тюмень (793,3), Омск $(407,0)$, Новосибирск $(152,9)$, Томск $(159,6)$, Северск $(520,7)$, Барнаул $(146,0)$, Бийск $(149,7)$, Кемерово $(643,3)$, Новокузнецк $(178,5)$, Красноярск $(595,4)$, Ачинск $(175,9)$, Кызыл $(173,4)$, Анграск $(243,4)$, Иркутск $(296,0)$, Закаменск $(185,3)$, Улан-Удэ $(152,9)$, Чита $(537,4)$, Краснокаменск $(953,3)$, Благовещенск $(298,3)$, Комсомольск-на-Амуре $(200,0)$, Владивосток $(111,6)$. Аномалии $\mathrm{Br}$ локализованы в зонах влияния крупных теплоэлектростанций, работающих на угле (Барнаул, Чита, Комсомольск-на-Амуре и др.); пространственное распределение аномальных концентра- ций согласуется с летними розами ветров (рис. 2, I-II), что свидетельствует о преимущественно аэротехногенном характере их формирования.

Высококонтрастные локальные аномалии $\mathrm{Br}$ также выявлены вблизи крупных транспортных узлов - авто-, железнодорожного и авиационного транспорта (Тюмень, Иркутск, Улан-Удэ и др.) (рис. 2, III-IV). По литературным данным отмечены высокие уровни накопления $\mathrm{Br}$ в атмосферном воздухе вблизи автодорог [29], а также в снеговом покрове вблизи аэропортов [30]. Известно, что в качестве антидетонационной добавки к авто- и авиатопливу используют дибромэтан [4].

Средние содержания Br выше нижнего аномального уровня зафиксированы на территориях приграничных городов Алтайского края (Славгород, Яровое, Рубцовск, Горняк) и сопредельных территориях Казахстана - Павлодарской (Экибастуз, Павлодар) и Восточно-Казахстанской областей (Усть-Каменогорск). 
Максимальное среднее и фактическое содержание $\mathrm{Br}$ установлено в г. Яровое - 393,0 и 1730,1 мг/кг соответственно. Урбанизированные территории с аномальным средним уровнем содержания $\mathrm{Br}$ выделены нами в Кулундинскую и Северо-Казахстанскую биогеохимические области и объединены в единую бромную биогеохимическую субпровинцию. Для сравнительного анализа были получены статистические параметры аномальных средних содержаний $\mathrm{Br}$ в золе листьев тополя ряда городов выделенной биогеохимической субпровинции и общей выборки проб, которые представлены в табл. 1.
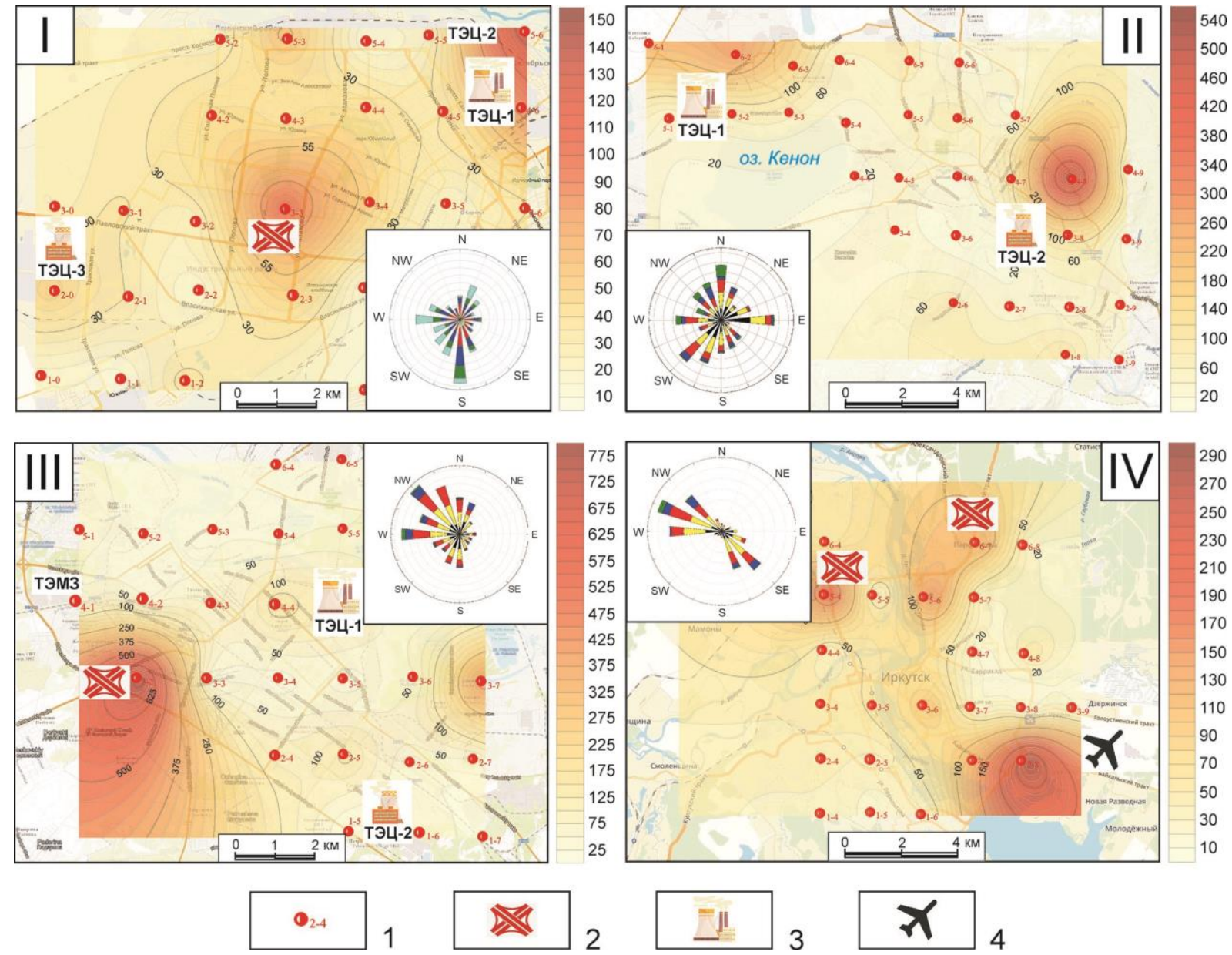

Pис. 2. Биогеохимические ореоль брома на территории городов: Барнаула (I), Читы (II), Тюмени (III), Иркутска (IV), по данным опробования листьев тополя. Условные обозначения: 1 - точки отбора проб и их номера, 2 развязки автомагистралей, 3 - теплоэлектростанции, 4 - аэропорт. Врезки - летние розы ветров, соответствующие сезону отбора проб. Изолинии содержания брома в золе листьев - в мг/кг

Fig. 2. Biogeochemical halos of bromine on the territory of cities: Barnaul (I), Chita (II), Tyumen (III), Irkutsk (IV), according to the sampling of poplar leaves. Legend: 1 - sampling points and their numbers, 2 - highway junctions, 3 - thermal power plants, 4 - airport. The insets are summer wind roses corresponding to the sampling season. Isolines of bromine content in leaf ash - in $\mathrm{mg} / \mathrm{kg}$

Таблица 1. Статистические параметры содержания $\mathrm{Br}$ (мг/кг) в золе листьев тополя

Table 1. Statistical parameters of bromine content $(\mathrm{mg} / \mathrm{kg})$ in the ash of poplar leaves

\begin{tabular}{|l|c|c|c|c|c|c|c|}
\hline \multicolumn{1}{|c|}{ Территория/город/Territory/City } & $\mathrm{N}$ & $\mathrm{X} \pm \lambda$ & $\mathrm{X}_{\text {геом }}$ & $\mathrm{Me}$ & $\mathrm{Min}-\mathrm{Max}$ & $\mathrm{S}$ & $\mathrm{V}$ \\
\hline Горняк/Gornyak & 16 & $124,8 \pm 20,5$ & 103,9 & 112,9 & $48,7 \ldots 323,3$ & 81,9 & 66 \\
\hline Рубцовск/Rubtsovsk & 19 & $119,6 \pm 21,2$ & 91,0 & 96,7 & $17,6 \ldots 396,4$ & 92,3 & 77 \\
\hline Славгород/Slavgorod & 12 & $114,2 \pm 16,1$ & 100,7 & 112,8 & $36,1 \ldots 214,0$ & 55,7 & 49 \\
\hline Яровое/Yarovoe & 9 & $393,0 \pm 177,6$ & 186,3 & 203,7 & $23,8 \ldots 1730,1$ & 532,8 & 136 \\
\hline Павлодар/Pavlodar & 27 & $144,1 \pm 12,5$ & 129,7 & 135,6 & $47,5 \ldots 279,8$ & 64,9 & 45 \\
\hline Экибастуз/Ekibastuz & 42 & $186,5 \pm 12,5$ & 168,7 & 178,7 & $66,6 \ldots 386,3$ & 82,0 & 44 \\
\hline Усть-Каменогорск/Ust-Kamenogorsk & 101 & $128,7 \pm 8,2$ & 110,9 & 110,8 & $21,1 \ldots 630,9$ & 81,5 & 63 \\
\hline Бромная субпровинция/Bromine subprovince & 226 & $150,0 \pm 9,2$ & 121,4 & 124,4 & $17,6 \ldots 1730,1$ & 137,8 & 92 \\
\hline Юг Сибири и ДВ/South Siberia and Far East & 1686 & $56,5 \pm 2,1$ & 29,0 & 30,6 & $0,3 \ldots 1730,1$ & 85,8 & 152 \\
\hline
\end{tabular}

Примечание: $N$ - количество проб в выборке, $X \pm \lambda$ - среднее арифметическое \pm оиибка среднего, $X_{\text {геом }}-$ среднее геометрическое, Ме - медиана, $S$ - стандартное отклонение, $V$ - коэффициент вариации (в \%).

Note: $N$ - number of samples, $X \pm \lambda$ - arithmetic mean terror of the mean, $X_{\text {геом }}$-geometric mean, $M e-m e d i a n, S-s t a n d a r d$ deviation, $V$ - coefficient of variation (\%). 
Проведенный кластерный анализ показателей всей выборки и бромной биогеохимической субпровинции позволил выделить ассоциации химических элементов и характер связи некоторых из них с $\mathrm{Br}$ (рис. 3).

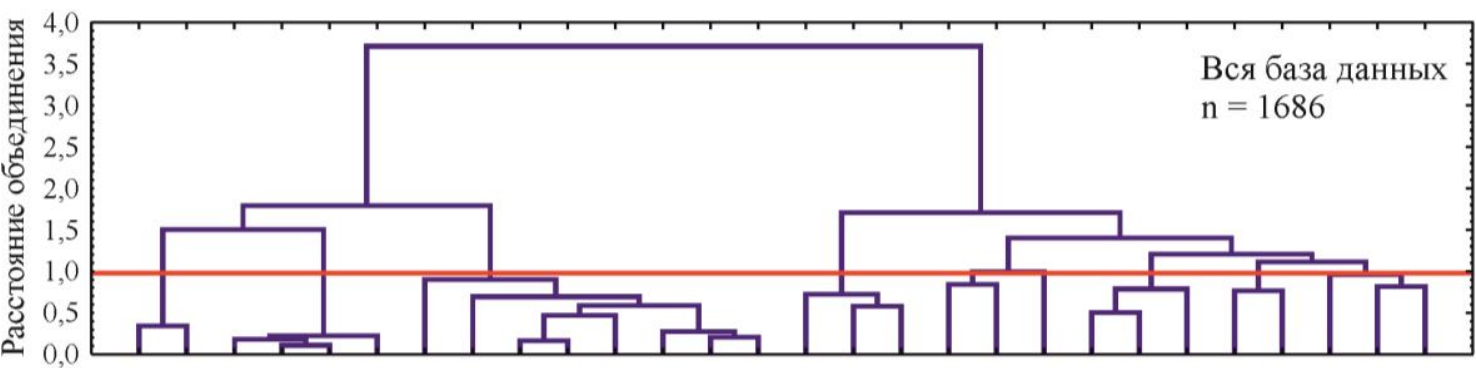

U Nd Tb Eu Sm La Fe Ta Lu Yb Ce Th Hf Se Ba Sr Ca Cs Rb Cr Sb As Zn Au Ag Co Br Na

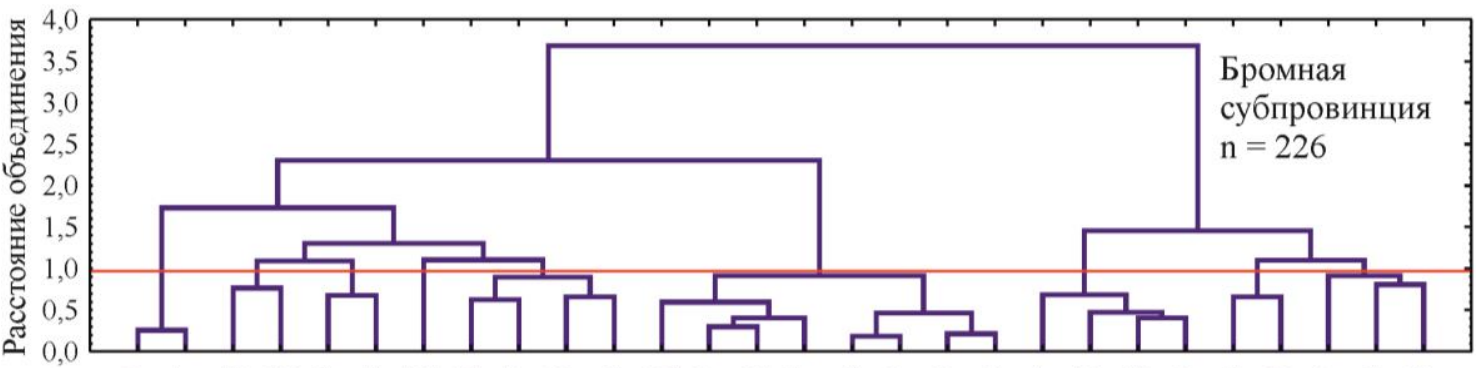

Br As U Nd Sr Co Tb Th Eu Ba Cr Hf Lu Yb Sm Ce La Fe Se Ag Ta Sb Zn Cs Rb Au Ca Na

Рис. 3. Дендрограммы корреляиионных матрии геохимического спектра элементов в золе листьев тополя выборок на территории юга Сибири и Дальнего Востока (сверху) и бромной биогеохимической субпровиниии (снизу); (Mетод Варда, 1-Pearson $r(0,05)=0,99 ; n$-объем выборки)

Fig. 3. Dendrogram for correlation matrix of geochemical spectrum of elements in the ash samples of the poplar leaves on the South of Siberia and the Far East territory (above) and of bromine biogeochemical subprovince (bottom); (Ward's Method, 1-Pearson $r(0,05)=0,99 ; n$ - number of samples)

Дендрограммы показывают, что в общей выборке существует несколько групп элементов, имеющих тесное геохимическое родство и образующих значимые ассоциации: 1 - U, Nd; 2 - Tb, Eu, Sm, La; 3 - Fe, $\mathrm{Ta}, \mathrm{Yb}, \mathrm{Lu}, \mathrm{Ce}$, Th, Hf, Sc; 4 - Ba, Sr, Ca; 5 - Cs, Rb; 6 - Sb, As, Zn; 7 - Au, Ag; 8 - Br, Na. В бромной биогеохимической субпровинции характер связи между элементами несколько отличается, наблюдаются следующие геохимические ассоциации: 1 - $\mathrm{Br}, \mathrm{As} ; 2-\mathrm{Sr}$, $\mathrm{Co} ; 3$ - Th, Eu, Ba, Cr; 4 - группа редкоземельных и рассеянных элементов с железом; 5 - Ag, Ta, $\mathrm{Sb}, \mathrm{Zn}$; 6 - Ca, Na. Связи U-Nd и Cs-Rb неизменны.

Для поиска и оценки параметров (содержания спектра химических элементов), по которым группа выборок с аномальным содержанием $\mathrm{Br}$ отличается от других территорий, а также для их классификации нами был использован дискриминантный анализ. По результатам дискриминантного анализа установлено, что по рассчитанным коэффициентам канонических переменных все исследованные территории в пределах бромной биогеохимической субпровинции уверенно выделяются содержаниями Сa и $\mathrm{Br}$ (табл. 2).

В пределах бромной субпровинции по значениям дискриминантной функции в координатах многомерных канонических переменных проведена классификация выборок с аномальным средним уровнем содержания Br. Результат представлен на рис. 4.
Таблица 2. Факторная структурная матрица канонических переменных элементного состава золь листьев тополя на территории городов в пределах бромной биогеохимической субпровиниии

Table 2. Factorial structural matrix of canonical variables of the elemental composition of poplar leaves ash in the cities within the bromine biogeochemical sub-province

\begin{tabular}{|c|c|c|c|c|c|}
\hline 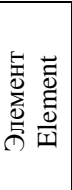 & 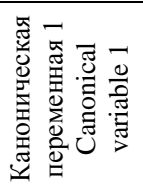 & 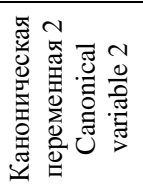 & 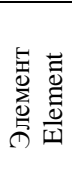 & 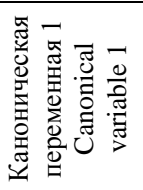 & 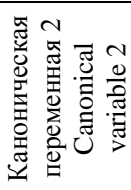 \\
\hline $\mathrm{Na}$ & 0,30 & $-0,30$ & $\mathrm{Ba}$ & $-0,33$ & 0,11 \\
\hline $\mathrm{Ca}$ & 0,51 & $-0,20$ & $\mathrm{La}$ & 0,36 & 0,49 \\
\hline $\mathrm{Sc}$ & $-0,07$ & 0,40 & $\mathrm{Ce}$ & $-0,34$ & $-0,19$ \\
\hline $\mathrm{Cr}$ & 0,04 & 0,48 & $\mathrm{Nd}$ & 0,09 & $-0,02$ \\
\hline $\mathrm{Fe}$ & 0,25 & $-0,06$ & $\mathrm{Sm}$ & $-0,79$ & $-0,06$ \\
\hline $\mathrm{Co}$ & $-0,16$ & 0,32 & $\mathrm{Eu}$ & $-0,05$ & $-0,05$ \\
\hline $\mathrm{Zn}$ & 0,07 & $-0,23$ & $\mathrm{~Tb}$ & $-0,02$ & $-0,23$ \\
\hline As & $-0,02$ & $-0,71$ & $\mathrm{Yb}$ & 0,07 & $-0,07$ \\
\hline $\mathrm{Br}$ & $-0,22$ & $\mathbf{0 , 5 7}$ & $\mathrm{Lu}$ & 0,00 & $-0,10$ \\
\hline $\mathrm{Rb}$ & 0,13 & $-0,18$ & $\mathrm{Hf}$ & $-0,18$ & 0,00 \\
\hline $\mathrm{Sr}$ & $-0,26$ & 0,00 & $\mathrm{Ta}$ & 0,07 & $-0,08$ \\
\hline $\mathrm{Ag}$ & $-0,04$ & $-0,03$ & $\mathrm{Au}$ & 0,05 & $-0,12$ \\
\hline $\mathrm{Sb}$ & 0,33 & $-0,03$ & Th & $-0,07$ & $-0,36$ \\
\hline Cs & 0,28 & 0,12 & $\mathrm{U}$ & $-0,17$ & 0,31 \\
\hline
\end{tabular}

Примечание: жирным (красным) шрифтом выделены максимальные положительные значения канонических переменных для кальция и брома.

Note: bold (red) font indicates maximum positive values of canonical variables for calcium and bromine. 


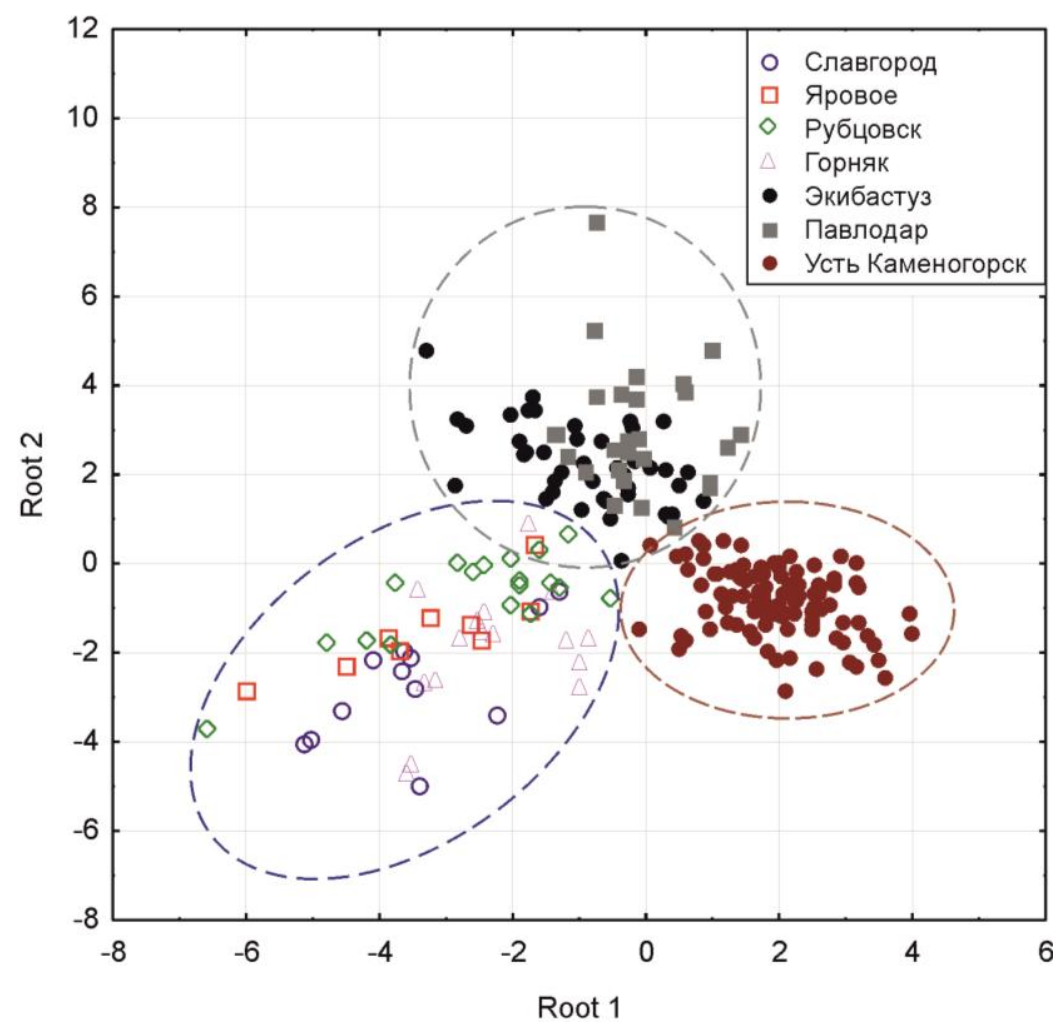

Pис. 4. График рассеяния канонических значений для канонических корней элементного состава золы листьев тополя на территории городов в пределах бромной биогеохимической субпровиниии

Fig. 4. Graph of scattering of canonical values for canonical roots of the elemental composition of the ash of poplar leaves in urban areas within the bromine biogeochemical subprovince

Существенно отличаются друг от друга по химическому составу золы листьев тополя три группы городов: 1) Славгород, Яровое, Рубцовск, Горняк; 2) Экибастуз, Павлодар; 3) Усть-Каменогорск. Первая группа расположена на территории Кулундинской бромной биогеохимической области; вторая и третья - на территории Северо-Казахстанской бромной биогеохимической области. Проанализированы и выявлены главные факторы, источники аномальных содержаний $\mathrm{Br}$ в каждой из областей.

В границах выделенной нами Кулундинской аномальной бромной области опробованы территории населенных пунктов: Славгород, Яровое, Горняк, Рубцовск, расположенных на юго-западе Алтайского края, в пределах лесостепной и степной ландшафтных зон с семиаридным климатом. В городах Славгород и Яровое в золе листьев тополя установлена значимая (95 \%) парная корреляционная связь $\mathrm{Br}$ с содержанием As; отрицательная корреляционная связь - с U. В г. Горняк выявлена значимая парная положительная корреляционная связь $\mathrm{Br}$ с $\mathrm{Na}$ и $\mathrm{U}$; в г. Рубцовск положительная корреляционная связь с Na, отрицательная - c Zn. Города Славгород и Яровое находятся в пределах Кулундинской степи (аллювиальной равнины), а Горняк и Рубцовск - в пределах Алейской степи (Предалтайской равнины).

Кулундинская степь, занимающая площадь около 100 тыс. км², имеет уникальную природную особенность - обилие (более 3 тыс.) пресных, соленых и горько-соленых бессточных озер, часть которых представлена крупными озерными месторождениями солей. Промышленные запасы $\mathrm{Br}$ сосредоточены в трех месторождениях (млн т): Кучукском $(0,079)$, Кулундинском $(0,164)$ и Большом Яровом $(0,040)$ [31]. Минерализация вод достигает 430 г/л при рН 7,2-9,9; главные их компоненты - хлорид натрия, хлорид магния, сульфат натрия, сульфат магния, карбонат натрия и бром. В озерных водах зафиксированы повышенные содержания (мг/л): $\mathrm{Br}$ до $820, \mathrm{~B}$ до 78, Li до 3,6 , I до 6,3 , As до 0,6 , U до 4,1 [32]. Рапа 03. Большое Яровое хлоридного натриево-магниевого состава с минерализацией 72,4 г/л. В рапе содержится $\mathrm{Br}$ в количестве 154 мг/л. С 1944 г. здесь работает завод по получению бромжелеза, используемого в военной промышленности, а также для фармацевтических предприятий. Основная часть расходного баланса озер приходится на испарение, величина которого в период открытой воды составляет 350-600 мм, что почти в два раза превышает количество атмосферных осадков (250-300 мм) [33]. Этот факт указывает на то, что источником аномальных содержаний $\mathrm{Br}$ является природный фактор - рассеивание брома в приземном слое атмосферы под действием климатических условий.

О региональном биогеохимическом влиянии данной области на компоненты природной среды сопредельных территорий говорят опубликованные результаты корреляционного и факторного анализов распределения химических элементов в золе годичных колец лиственницы (Larix sibirica Ledeb.) [34]. 
На территории Западного Алтая выделяется ассоциация химических элементов, которая представлена щелочными металлами и галогенами $(\mathrm{Na}, \mathrm{Ca}, \mathrm{Br}$ и др.). Для нее характерно превышение фоновых концентраций в среднем более чем в 5 раз. В годичных кольцах лиственницы в пространственном распределении выделенных элементов, включая $\mathrm{Br}$, проявлено уменьшение их содержаний в направлении с северозапада на юго-восток, что, предположительно, указывает на их поступление с пыльными бурями с территории Степного Алтая, возможно, с соленых озер и засоленных почв Кулундинской равнины.

В границах Северо-Казахстанской аномальной бромной области опробованы территории следующих городов: Экибастуз, Павлодар и Усть-Каменогорск.

На территории г. Экибастуз среднее содержание $\mathrm{Br}$ в золе листьев тополя (42 пробы) составляет $186,5 \pm 12,5$ мг/кг, максимальное - 386,3 мг/кг. Среднее содержание $\mathrm{Br}$ в золе листьев тополя г. Экибастуз в 3,3 раза выше среднего регионального значения (табл. 1). Кроме того, установлена значимая положительная парная корреляционная связь $\mathrm{Br}$ c Sc, Fe, $\mathrm{Co}$, $\mathrm{Zn}$ и легкими РЗЭ. Вероятно, источником эмиссии $\mathrm{Br}$ в окружающую среду г. Экибастуз являются открытая разработка угля (разрезы Богатырь, Восточный, Сeверный) и выбросы крупнейших теплоэлектростанций ГРЭС-1 и ГРЭС-2, вырабатывающих электроэнергию из углей Экибастузского и Майкубенского бассейнов. Первая станция потребляет угля свыше 9 млн т, вторая - около 4 млн т в год [35]. Угли месторождений высокозольные (более 40 \%), с высоким содержанием примесей. Недостаточная очистка выбросов золоулавливающими установками приводит к поступлению значительных объемов мелкодисперсных аэрозолей в атмосферу - 46 \% всех выбросов вредных веществ области, из них 94 \% приходится на ГРЭС-1 и ГРЭС-2. На расстоянии до 15 км от станций концентрации пыли превышают ПДК в 10 и более раз, газовые компоненты выбросов - $\mathrm{SO}_{2}$ и $\mathrm{NO}$ обнаруживаются на расстоянии 120 км [36].

Город Павлодар расположен в 120 км от г. Экибастуз по направлению преобладающих ветров. Максимальное содержание $\mathrm{Br}$ в выборке (27 проб) г. Павлодара составляет 279,8 мг/кг, среднее $144,1 \pm 12,5$ мг/кг, что в 2,5 раза выше среднего регионального значения (табл. 1). Кроме того, для состава золы листьев тополя с территории этого города установлены значимые отрицательные парные корреляционные связи $\mathrm{Br}$ с содержаниями $\mathrm{Sc}, \mathrm{Cr}, \mathrm{Fe}, \mathrm{Sb}, \mathrm{Th}$ и Р3Э. Спектр химических элементов указывает на возможное влияние угольных производств Экибастузских ГРЭС-1 и ГРЭС-2 и ферросплавного завода г. Аксу [36]. Косвенным доказательством ветрового переноса является наложение выборок г. Павлодар и

\section{СПИСОК ЛИТЕРАТУРЫ}

1. Иванов В.В. Экологическая геохимия элементов: Справочник В 6 кн. / под ред. Э.К. Буренкова. Кн. 3: Редкие р-элементы. М.: Недра, 1996. -352 c.

2. Перельман А.И. Геохимия элементов в зоне гипергенеза. - M.: Недра, 1972. - 288 с. г. Экибастуз в координатах многомерных канонических переменных (рис. 4).

Максимальное содержание $\mathrm{Br}$ в выборке (101 проба) г. Усть-Каменогорск составляет 630,9 мг/кг, сред-

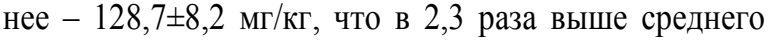
регионального значения (табл. 1). Максимальное и повышенные содержания $\mathrm{Br}$ зафиксированы в районе действия титано-магниевого комбината и Согринской ТЭЦ [37]. Установлены значимые положительные парные корреляционные связи $\mathrm{Br}$ с содержаниями $\mathrm{Na}$, $\mathrm{Co}$, As и U; отрицательные корреляционные связи с содержаниями Са и Ва.

Несмотря на наличие локальных аномалий техногенного генезиса, общей особенностью содержания $\mathrm{Br}$ в выборках Северо-Казахстанской бромной области является невысокий коэффициент вариации (44-63 \%) при близких значениях средних и медианы (табл. 1), что говорит об относительно однородном распределении элемента. Этот факт свидетельствует о природно-техногенном источнике его нахождения в данной области.

\section{Выводы}

1. Средний региональный уровень содержания $\mathrm{Br}$ в золе листьев тополей, произрастающих на урбанизированных территориях юго-востока Евразии, по данным ИНАА, составил 56,5 $\pm 2,1$ мг/кг, медиана - 30,6 мг/кг. Нижний аномальный уровень содержания $\mathrm{Br}$ (с учетом логнормального закона распределения) составляет 103,4 мг/кг.

2. Локальные биогеохимические аномалии $\mathrm{Br}$ закартированы на территориях, находящихся в зоне воздействия крупных теплоэлектростанций, вблизи транспортных узлов - автомобильного, железнодорожного и авиационного.

3. Выявлены две сопряженные аномальные бромные биогеохимические области: Кулундинская - преимущественно природного генезиса и СевероКазахстанская - природно-техногенного генезиса. По территориальному принципу биогеохимического районирования эти области объединены в бромную биогеохимическую субпровинцию.

4. Полученные данные могут найти применение для мониторинга эколого-геохимического состояния урбанизированных территорий, для изучения закономерностей формирования биогеохимических провинций, а также при обновлении карты биогеохимического районирования России и сопредельных территорий.

Научные исследования выполнены в рамках программы повышения конкурентоспособности ТПУ среди ведущих мировых исследовательских иентров. Обработка данных и интерпретация результатов выполнена в рамках реализаџии гранта Российского научного фонда (проект № 20-64-47021).

3. Vainikka P., Hupa M. Review on bromine in solid fuels. P. 1: Natural occurrence // Fuel. - 2012. - № 95. - P. 1-14.

4. Vainikka P., Hupa M. Review on bromine in solid fuels. P. 2: Anthropogenic occurrence // Fuel. - 2012. - № 94. - P. 34-51.

5. Ketris M.P., Yudovich Ya.E. Estimations of Clarkes for Carbonaceous biolithes: world averages for trace element contents 
in black shales and coals // International Journal of Coal Geology. - 2009. - № 78. - Р. 135-148.

6. Демаков В.А. Бромированные алкилы как промышленные яды и атмосферные загрязнения: автореф. дис. ... канд. мед. наук. - Пермь, 1975. - $16 \mathrm{c}$.

7. Пастухова О.М. Изучение специфического влияния выбросов предприятий галоидорганического синтеза в натурных экспериментах и наблюдениях: автореф. дис .... канд. мед. наук. Оренбург, 1999. - $18 \mathrm{c}$

8. Красовицкая М.Л. Галоидпроизводные углеводородов как атмосферные загрязнители. - Пермь: Кн. изд-во, 1976. - 142 с.

9. Winid B. Bromine and water quality - selected aspects and future perspectives // Applied Geochemistry. - 2015. - V. 63. - P. 413-435.

10. Юдович Я.Э., Кетрис М.П. Ценные элементы-примеси в углях. - Екатеринбург: УрО РАН, 2006. - 422 с.

11. Bromine compounds. Ullmann's Encyclopedia of Industrial Chemistry / D. Yoffe, R. Frim, S.D. Ukeles, M.J. Dagani, H.J. Barda, T.J. Benya, D.C. Sanders. - 2013. - 31 p. URL: https://onlinelibrary.wiley.com/doi/abs/10.1002/14356007.a04_40 5.pub2 (дата обращения 15.10.2020).

12. Comparative study on susceptibility tu 1-brompropane in three mice strains / Liu Fang, Ichihara Sahoko, Mohideen Sahabudeen Sheik, Sai Uka, Kitoh Junzoh, Ichihara Gaku // Toxicological Sciences. - 2009. - V. 112. - № 1. - P. 100-120.

13. Melatonin pretreatment attenuales 2-bromopropane - induced testicular toxicity in rats / Huang Fen, Ning Huan, Xin QianQuan, Huagn Jong, Wang Hua, Zhang Zhi-Hua, Xu De-Xiang, Ichihara Gaku, Je Dong-Qing // Toxicology. - 2009. - V. 256. - № 1-2. P. $75-82$.

14. Regional variation and porrible sources of brominated contaminants in breast milk from Japan / Fujii Yukoko, Ito Yoshiko, Harada Kouji H., Hitomi Toshaki, Koizumi Akio, Haraguchi Koichi // Environmental Pollution. - 2012. - № 162. P. 269-274

15. Carr H.S., Rozenkranz H.S. Mutagenicity of derivatives of the flame retardant tris (2.3-dibromopropyl)phosphate: halogenated-propanols // Mutation Research. - 1978. - V. 57. № 7. - P. 381-384.

16. Buchberger W., Holler W., Winsauer K. Effects of sodium bromide on the biosynthesis of thyroid hormones and brominated/iodinated thyronines // J. Trace Elem. and Electrolytes Health and Disease. - 1990. - V. 4. - № 1. - P. 25-30.

17. Арбузова Т.П., Пастухова О.М., Демаков В.А. Микроэлементы-галогены и их соединения как загрязнители окружающей среды. Риск для здоровья населения (обзор литературы) // Здоровье семьи - 21 век. - 2013. - № 4 (4). - С. 1-20.

18. Towards integrating toxicity characterization into environmental studies: case study of bromine in soils / T. Bratec, N. Kirchhübel, N. Baranovskaya, B. Laratte, O Jolliet., L. Rikhvanov, P. Fantke // Environmental Science and Pollution Research. - 2019. № 26 (19). - P. 19814-19827. URL: https://doi.org/10.1007/s11356019-05244-5 (дата обращения 15.10.2020)

19. Trace element biomonitoring by leaves of Populus nigra L. from Western Anatolia, Turkey / S. Baslar, Y. Dogan, N. Yenil, S. Karagoz, H. Bag // Journal of Environmental Biology. - 2005. № 26. - P. 665-668.

20. Trace element composition of poplar in Mongolian cities / N.E. Kosheleva, I.V. Timofeev, N.S. Kasimov, T.M. Kiselyova, A.V. Alekseenko, O.I. Sorokina // Biogenic- abiogenic interactions in natural and anthropogenic systems. Lecture Notes in Earth System Sciences / Eds. O.V. Frank-Kamenetskaya et al. Switzerland: Springer, 2016. - P. 165-177.

21. Rare earth elements in poplar leaves as indicators of geological environment and technogenesis / D.V. Yusupov, N.V. Baranovskaya, Yu.V. Robertus, V.V. Radomskaya, L.M. Pavlova, A.F. Sudyko, L.P. Rikhvanov // Environmental Science and Pollution Research. 2020. - V. 27. - P. 27111-27123. URL: https://doi.org/ 10.1007/s11356-020-09090-8 (дата обращения 15.10.2020).
22. Terekhina N.V., Ufimtseva M.D. Leaves of trees and shrubs as bioindicators of air pollution by particulate matter in Saint Petersburg // Geography, Environment, Sustainability. - 2020. № 13 (1). - P. 224-232. URL: https://doi.org/10.24057/20719388-2019-65 (дата обращения 15.10.2020).

23. Ташекова А.Ж., Торопов А.С. Использование листьев растений как биогеохимических индикаторов состояния городской среды // Известия Томского политехнического университета. Инжиниринг георесурсов. - 2017. - Т. 328. - № 5. - С. 114-124.

24. Goodman G.T., Roberts T.M. Plants and soils as indicators of metals in the air // Nature, Load. -1971. - № 231. - P. 287-292.

25. Manual on methods and criteria for harmonized sampling, assessment, monitoring and analysis of the effects of air pollution on forests. P. IV: Sampling and analysis of needles and leaves / K. Stefan, H. Raitio, U. Bartels, A. Fürst. - Geneva: UN-ECE, ICP Forests, 2000. $-47 \mathrm{p}$.

26. ГОСТ 26929-94 Сырье и продукты пищевые. Подготовка проб. Минерализация для определения содержания токсичных элементов. - М.: ИПК Издательство стандартов, 2002. - 31 р.

27. Shtangeeva I. Bromine accumulation in some crops and grasses as determined by neutron activation analysis // Communications in soil science and plant analysis. - 2017. - V. 48. - № 19. P. 2338-2346. URL: https://doi.org/10.1080/00103624.2017. 1411511 (дата обращения 15.10.2020).

28. Инструкция по геохимическим методам поисков рудных месторождений / под ред. Л.Н. Овчинников и др. - М.: Недра, 1983. - $191 \mathrm{c}$

29. Yatin M., Tuncel S.G., Tuncel G. Trace element composition of atmospheric aerosols in Ankara, Turkey, determined by instrumental neutron activation analysis // Journal of Radioanalytical and Nuclear Chemistry. - 1994. - V. 181 (2). P. 401-411.

30. Zikovsky L. An indirect study of air pollution by neutron activation analysis of snow // Journal of Radio analytical and Nuclear Chemistry. - 1986. - V. 114 (1). - P. 147-153.

31. Геология СССР. Т. ХIV. Западная Сибирь (Кемеровская, Новосибирская, Омская, Томская области, Алтайский край). Полезные ископаемые. Кн. 2 / под ред. В.И. Бгатова и др. - М.: Недра, 1982. - 196 c.

32. Uranium in the mineralized lakes of Altai krai / V.P. Isupov, S.S. Shatskaja, N.Z. Lyakhov, M.N. Kolpakova, S.L. Shvartsev, S.V. Borzenko, A.P. Dolgushin, G.M. Arzamasova // Doklady Earth Sciences. - 2016. - V. 470 (2). - P. 1067-1070.

33. Гидрохимия и геохимическая типизация соленых озер степной части Алтайского края / М.Н. Колпакова, С.В. Борзенко, В.П. Исупов, С.С. Шацкая, С.Л. Шварцев // Вода: химия и экология. - 2015. - № 1. - С. 11-16.

34. Робертус Ю.В., Рихванов Л.П., Любимов Р.В. Дендрогеохимическая индикация трансграничных переносов экотоксикантов на территорию Алтая // Известия Томского политехнического университета. - 2010. - Т. 317. - № 1. - С. 173-177.

35. Радиоактивные элементы (торий, уран) в листьях тополя на урбанизированных территориях и их индикаторная роль / Д.В. Юсупов, Л.П. Рихванов, А.Ф. Судыко, Н.В. Барановская, Л.А. Дорохова // Разведка и охрана недр. - 2019. - № 2. С. $61-68$.

36. Биоиндикация урбоэкосистемы г. Павлодара по содержанию химических элементов в золе листвы тополя черного (Populus nigra L.) / Б.Х. Шаймарданова, Г.Е. Асылбекова, Н.В. Барановская, А.Б. Бигалиев, Н.П. Корогод // Вестник Томского государственного университета. - 2010. - № 338. - С. 212-216.

37. Populus nigra L. as a bioindicator of atmospheric trace element pollution and potential toxic impacts on human and ecosystem / A. Yalaltdinova, J. Kim, N. Baranovskaya, L. Rikhvanov // Ecological Indicators. - 2018. - № 95. - P. 974-983.

Поступила 23.12.2020 2.

\section{Информация об авторах}

Юсупов Д.В., кандидат геолого-минералогических наук, доцент кафедры геологии и природопользования Амурского государственного университета; доцент отделения геологии Инженерной школы природных ресурсов Национального исследовательского Томского политехнического университета. 
Рихванов Л.П., доктор геолого-минералогических наук, профессор отделения геологии Инженерной школы природных ресурсов Национального исследовательского Томского политехнического университета.

Барановская Н.B., доктор биологических наук, профессор отделения геологии Инженерной школы природных ресурсов Национального исследовательского Томского политехнического университета.

Робертус Ю.В., кандидат геолого-минералогических наук, ведущий научный сотрудник Института водных и экологических проблем СО РАН.

Радомская В.И., кандидат химических наук, ведущий научный сотрудник лаборатории биогеохимии Института геологии и природопользования ДВО РАН.

Павлова Л.М., кандидат биологических наук, ведущий научный сотрудник лаборатории биогеохимии Института геологии и природопользования ДВО РАН.

Дорохова Л.А., аспирант отделения геологии Инженерной школы природных ресурсов Национального исследовательского Томского политехнического университета; младший научный сотрудник лаборатории биогеохимии Института геологии и природопользования ДВО РАН.

Cydыко А.Ф., инженер отделения геологии Инженерной школы природных ресурсов Национального исследовательского Томского политехнического университета. 
UDC 546.14:581.45:582.681.82:550.42

\section{BROMINE IN THE POPLAR LEAVES OF URBAN AREAS: NATURAL AND ANTHROPOGENIC SOURCES OF SCATTERING}

\author{
Dmitry V. Yusupov ${ }^{1,2}$, \\ yusupovd@mail.ru
}

Leonid P. Rikhvanov2

Natalia V. Baranovskaya², nata@tpu.ru

Yuriy V. Robertus ${ }^{3}$, ariecol@mail.gorny.ru

\author{
Valentina I. Radomskaya ${ }^{4}$, \\ radomskaya@ascnet.ru
}

Lyudmila M. Pavlova4, pav@ascnet.ru

Lyubov A. Dorokhova2,4, liubov.ad@yandex.ru

\author{
Alexander F. Sudyko², \\ sudykoaf@yandex.ru
}

${ }^{1}$ Amur State University, 21, Ignatievskoe highway, Blagoveshchensk, 675027, Russia.

2 National Research Tomsk Polytechnic University, 30, Lenin avenue, Tomsk, 634050, Russia.

3 Institute for Water and Environmental Problems SB RAS, 1, Molodezhnaya street, Barnaul, 656038, Russia.

4 Institute of Geology and Nature Management FEB RAS,

1, Relochny lane, Blagoveshchensk, 675000, Russia.

Relevance of the work. Bromine is a tolassophilic, organophilic and essential element. The combination of natural and anthropogenic sources of dispersion of this element determines the complexity and multifactorial nature of its entry into the environment, affects the characteristics of halogen accumulation and distribution in natural environments. The main attention in the work is focused on urbanized areas of the local and regional levels of the study with sources of Br emission. The migration routes and biogeochemical accumulation of bromine remain poorly studied issues.

The main aim of the research is to determine the quantitative content of $\mathrm{Br}$ in the leaves of woody plants of the genus poplar (Populus L.), growing in urbanized areas of South-East Eurasia, and based on the principles of biogeochemical zoning to identify the halos of Br load, determine the main factors of their formation.

Methods. Poplar leaves (Populus L.) served as the object of the study. Sampling was carried out in August 2015-2018 on the territory of more than 50 cities along a uniform network with a step of $1 \times 1$ and $2 \times 2 \mathrm{~km}$. The average sample size in cities was 30 samples. In total, about 1700 samples of poplar leaves were taken. Leaf ash was carried out by dry mineralization in a muffle furnace at $450^{\circ} \mathrm{C}$ for 5 hours. The authors have taken into account the literature data that $\mathrm{Br}$ loss in the ash obtained at $400{ }^{\circ} \mathrm{C}$ was no more than $20 \%$ of the calculated value. Content of $\mathrm{Br}$ and other chemical elements in the ash of poplar leaves was determined by the method of instrumental neutron activation analysis in the nuclear geochemical laboratory at the educational research nuclear reactor (IRT-T) at Tomsk Polytechnic University. The analysis results were processed using descriptive statistics, cluster and discriminant analyzes.

Results. The average $\mathrm{Br}$ content in the ash of poplar leaves in urbanized areas was $56,5 \pm 2,1 \mathrm{mg} / \mathrm{kg}$, with a range from 0,3 to $1730,1 \mathrm{mg} / \mathrm{kg}$. The median is 30,6 mg/kg. The lower anomalous Br content was 103,4 mg/kg. Two conjugated anomalous bromine biogeochemical regions were revealed: Kulunda - natural genesis and North Kazakhstan - natural and technogenic genesis. Areas are depleted in area in bromine biogeochemical subprovince, first described in this work.

\section{Key words:}

Biogeochemical indication, poplar leaves, bromine, instrumental neutron activation analysis, urban areas.

The research was carried out within the Program of enhancement of TPU competitiveness among the leading world's research centers. Data processing and interpretation of the results were performed within the framework of the grant from the Russian Science Foundation (project no. 20-64-47021).

\section{REFERENCES}

1. Ivanov V.V. Ekologicheskaya geokhimiya elementov: Spravochnik Kn. 3: Redkie p-elementy [Environmental geochemistry of elements. B. 3. Rare p-elements]. Ed. by E.K. Burenkov. Moscow, Nedra Publ., 1996. 352 p.

2. Perelman A.I. Geokhimiya elementov $v$ zone gipergeneza [Geochemistry of elements in the hypergenesis zone]. Moscow, Nedra Publ., 1972. 288 p.

3. Vainikka P., Hupa M. Review on bromine in solid fuels. P. 1: Natural occurrence. Fuel, 2012, vol. 95, pp. 1-14.
4. Vainikka P., Hupa M. Review on bromine in solid fuels. P. 2: Anthropogenic occurrence. Fuel, 2012, vol. 94, pp. 34-51.

5. Ketris M.P., Yudovich Ya.E. Estimations of Clarkes for Carbonaceous biolithes: world averages for trace element contents in black shales and coals. International Journal of Coal Geology, 2009, vol. 78, pp. 135-148.

6. Demakov V.A. Bromirovannye alkily kak promyshlennye yady $i$ atmosfernye zagryazneniya. Avtoreferat Diss. Kand. nauk [Brominated alkyls as industrial poisons and atmospheric pollutants. Cand. Diss. Abstract]. Perm, 1975. 16 p. 
7. Pastukhova O.M. Izuchenie spetsificheskogo vliyaniva vybrosov predpriyatiy galoidorganicheskogo sinteza $v$ naturnykh eksperimentakh i nablyudeniyakh. Avtoreferat Diss. Kand. nauk [Study of the specific effect of emissions from enterprises of organohalide synthesis in field experiments and observations. Cand. Diss. Abstract]. Orenburg, 1999. 18 p.

8. Krasovickaya M.L. Galoidproizvodnye uglevodorodov kak atmosfernye zagryazniteli [Halide derivatives of hydrocarbons as atmospheric pollutants]. Perm, Knizhnoe izdatelsvo, 1976. 142 p.

9. Winid B. Bromine and water quality e Selected aspects and future perspectives. Applied Geochemistry, 2015, vol. 63, pp. 413-435.

10. Yudovich Ya.E., Ketris M.P. Tsennye elementy-primesi v uglyakh [Valuable trace elements in coals]. Ekaterinburg, UrO RAS Publ., 2006. $422 \mathrm{p}$.

11. Yoffe D., Frim R., Ukeles S.D., Dagani M.J., Barda H.J., Benya T.J., Sanders D.C. Bromine compounds. Ullmann's Encyclopedia of Industrial Chemistry, 2013. 31 p. Available at: https://onlinelibrary.wiley.com/doi/abs/10.1002/14356007.a04_40 5.pub2 (accessed 15 October 2020).

12. Liu Fang, Ichihara Sahoko, Mohideen Sahabudeen Sheik, Sai Uka, Kitoh Junzoh, Ichihara Gaku. Comparative study on susceptibility tu 1-brompropane in three mice strains. Toxicological Sciences, 2009, vol. 112, no. 1, pp. 100-120.

13. Huang Fen, Ning Huan, Xin Qian Quan, Huagn Jong, Wang Hua, Zhang Zhi-Hua, Xu De-Xiang, Ichihara Gaku, Je Dong-Qing. Melatonin pretreatment attenuales 2-bromopropane - inducend testicular toxicity in rats. Toxicology, 2009, vol. 256, no. 1-2, pp. 75-82.

14. Fujii Yukoko, Ito Yoshiko, Harada Kouji H., Hitomi Toshaki, Koizumi Akio, Haraguchi Koichi. Regional variation and porrible sources of brominated contaminants in breast milk from Japan. Environmental Pollution, 2012, no. 162, pp. 269-274.

15. Carr H.S., Rozenkranz H.S. Mutagenicity of derivatives of the flame retardant tris (2.3-dibromopropyl) phosphate: halogenatedpropanols. Mutation Research, 1978, vol. 57, no. 7, pp. 381-384.

16. Buchberger W., Holler W., Winsauer K. Effects of sodium bromide on the biosynthesis of thyroid hormones and brominated/iodinated thyronines. J. Trace Elem. and Electrolytes Health and Disease, 1990. vol. 4, no. 1, pp. 25-30.

17. Arbuzova T.P., Pastuhova O.M., Demakov V.A. Trace elementsHalogens and their compounds as pollutants of the environment. The risk to public health (review of literature). Zdorov'e sem'i 21 vek, 2013. vol. 4, no. 4, pp. 1-20. In Rus.

18. Bratec T., Kirchhübel N., Baranovskaya N., Laratte B., Jolliet O., Rikhvanov L., Fantke P. Towards integrating toxicity characterization into environmental studies: case study of bromine in soils. Environmental Science and Pollution Research, 2019, vol. 26, no. 19, pp. 19814-19827. Available at: https://doi.org/10.1007/ s11356-019-05244-5 (accessed 15 October 2020).

19. Baslar S., Dogan Y., Yenil N., Karagoz S., Bag H. Trace element biomonitoring by leaves of Populus nigra L. from Western Anatolia, Turkey. Journal of Environmental Biology, 2005, vol. 26 , pp. 665-668.

20. Kosheleva N.E., Timofeev I.V., Kasimov N.S., Kiselyova T.M., Alekseenko A.V., Sorokina O.I. Trace element composition of poplar in Mongolian cities. Biogenic - abiogenic interactions in natural and anthropogenic systems. Lecture Notes in Earth System Sciences. Ed. by O.V. Frank-Kamenetskaya. Switzerland, Springer, 2016. pp. 165-177.

21. Yusupov D.V., Baranovskaya N.V., Robertus Yu.V., Radomskaya V.V., Pavlova L.M., Sudyko A.F., Rikhvanov L.P. Rare earth elements in poplar leaves as indicators of geological environment and technogenesis. Environmental Science and Pollution Research, 2020, vol. 27, pp. 27111-27123. Available at: https://doi.org/ 10.1007/s11356-020-09090-8 (accessed 15 October 2020).

22. Terekhina N.V., Ufimtseva M.D. Leaves of trees and shrubs as bioindicators of air pollution by particulate matter in Saint Petersburg. Geography, Environment, Sustainability, 2020, vol. 13 , no. 1, pp. 224-232. Available at: https://doi.org/10.24057/20719388-2019-65 (accessed 15 October 2020).
23. Tashekova A.Zh., Toropov A.S. Use of plant leaves as biogeochemical indicators of the state of the urban environment. Bulletin of the Tomsk Polytechnic University. Geo-Resource Engineering, 2017, vol. 328, no. 5, pp. 114-124. In Rus.

24. Goodman G.T., Roberts T.M. Plants and soils as indicators of metals in the air. Nature, Load, 1971, vol. 231, pp. 287-292.

25. Stefan K., Raitio H., Bartels U., Fürst A. Manual on methods and criteria for harmonized sampling, assessment, monitoring and analysis of the effects of air pollution on forests. Part IV: Sampling and analysis of needles and leaves. Geneva, UN-ECE, ICP Forests, 2000. $47 \mathrm{p}$.

26. GOST 26929-94. Syre i produkty pishchevye. Podgotovka prob. Mineralizatsiya dlya opredeleniya soderzhaniya toksichnykh elementov [State standard 26929-94. Raw materials and food products. Sample preparation. Mineralization for determination of the toxic element contents]. Moscow, IPK standards Publ. house, 2002. $31 \mathrm{p}$.

27. Shtangeeva I. Bromine accumulation in some crops and grasses as determined by neutron activation analysis. Communications in soil science and plant analysis, 2017, vol. 48, no. 19, pp. 2338-2346. Available at: https://doi.org/10.1080/00103624.2017.1411511 (accessed 15 October 2020).

28. Instruktsiya po geokhimicheskim metodam poiskov rudnykh mestorozhdeniy [Instructions on geochemical methods of searching for ore deposits]. Ed. by L.N. Ovchinnikov. Moscow, Nedra Publ., 1983. 191 p.

29. Yatin M., Tuncel S.G., Tuncel G. Trace element composition of atmospheric aerosols in Ankara, Turkey, determined by instrumental neutron activation analysis. Journal of Radioanalytical and Nuclear Chemistry, 1994, vol. 181, no. 2, pp. 401-411.

30. Zikovsky L. An indirect study of air pollution by neutron activation analysis of snow. Journal of Radio analytical and Nuclear Chemistry, 1986, vol. 114, no. 1, pp. 147-153.

31. Geologiva SSSR. T. XIV. Zapadnaya Sibir (Kemerovskaya, Novosibirskaya, Omskaya, Tomskaya oblasti, Altayskiy kray). Poleznye iskopaemye. Kn. 2 [Geology of the USSR. V. XIV. Western Siberia (Kemerovo, Novosibirsk, Omsk, Tomsk regions, Altai Territory). Minerals]. Ed. by V.I. Bgatov. Moscow, Nedra Publ., 1982. $196 \mathrm{p}$.

32. Isupov V.P., Shatskaja S.S., Lyakhov N.Z., Kolpakova M.N., Shvartsev S.L., Borzenko S.V., Dolgushin A.P., Arzamasova G.M. Uranium in the mineralized lakes of Altai krai. Doklady Earth Sciences, 2016, vol. 470, no. 2, pp. 1067-1070.

33. Kolpakova M.N., Borzenko S.V., Isupov V.P., Shatskaya S.S., Shvartsev S.L. Hydrochemistry and geochemical typification of salt lakes in the steppe part of Altai Krai. Water: chemistry and ecology, 2015, vol. 1, pp. 11-16. In Rus.

34. Robertus Yu.V., Rihvanov L.P., Lyubimov R.V. Dendrogeochemical indication of transboundary transfers of ecotoxicants to the territory of Altai. Bulletin of the Tomsk Polytechnic University, 2010, vol. 317, no. 1, pp. 173-177. In Rus.

35. Yusupov D.V., Rihvanov L.P., Sudyko A.F., Baranovskaya N.V., Dorohova L.A. Radioactive elements (thorium, uranium) in poplar leaves in urban areas and their indicator role. Razvedka $i$ ohrana $n e d r, 2019$, vol. 2, pp. 61-68. In Rus.

36. Shaimardanova B.Kh., Asylbekova G.E., Baranovskaya N.V., Bigaliev A.B., Korogod N.P. Bioindication of urban system of Pavlodar on the content of chemical elements in black poplar leaf ash Populus nigra L. Vestnik Tomskogo gosudarstvennogo universiteta, 2010, no. 338, pp. 212-216. In Rus.

37. Yalaltdinova A., Kim J., Baranovskaya N., Rikhvanov L. Populus nigra $\mathrm{L}$. as a bioindicator of atmospheric trace element pollution and potential toxic impacts on human and ecosystem. Ecological Indicators, 2018, vol. 95, P. 2, pp. 974-983. Available at: https://doi.org/10.1016/j.ecolind.2017.06.021 (accessed 15 October 2020).

Received: 23 December 2020. 


\section{Information about the authors}

Dmitry V. Yusupov, Cand. Sc., assistant professor, Amur State University; associate professor, National Research Tomsk Polytechnic University.

Leonid P. Rikhvanov, Dr. Sc., professor, National Research Tomsk Polytechnic University.

Natalia V. Baranovskaya, Dr. Sc., professor, National Research Tomsk Polytechnic University.

Yuriy V. Robertus, Cand. Sc., leading researcher, Institute for Water and Environmental Problems (IWEP SB RAS).

Valentina I. Radomskaya, Cand. Sc., leading researcher, Institute of Geology and Nature Management FEB RAS.

Lyudmila M. Pavlova, Cand. Sc., leading researcher, Institute of Geology and Nature Management FEB RAS.

Lyubov A. Dorokhova, post-graduate student, National Research Tomsk Polytechnic University; junior researcher, Institute of Geology and Nature Management FEB RAS.

Alexander F. Sudyko, engineer, National Research Tomsk Polytechnic University. 